\title{
PENINGKATAN PENERAPAN CONTEXTUAL TEACHING AND LEARNING MELALUI STRATEGI PEMODELAN DAN PEMBERIAN TUGAS SEBAGAI TINDAK LANJUT SUPERVISI AKADEMIK
}

\section{Oleh}

\author{
Abdulah $^{1}$
}

\section{Abstract}

Abdulah.2011.The improvement of Contextual Teaching and Learning Application through Task and Model Strategy as the Sustainable Academic Supervision

The study is based on the weakneses of Bahasa Indonesia teacher of SMP Negeri 4 Sungai Ambawang in appliying of the Contextual Teaching and Learning Approach on Bahasa Indoneaia subject. The CTL approach is intended to make the atmosphere of learning teaching proses enjoyable for the students.

The issues of is study is how well the plan, the action and the evaluation conducted to improve the Contextual Teaching and Learning application through Task and Model Strategy as the sustainable of Academic Supervision of SMP Negeri 4 Sungai Ambawang. Academic Supervision of SMP Negeri 4 Sungai Ambawang. Academic Year 2010-2011.

The study designed is the school Action Reaseach, by descriptive mettod and qualitative study form. The students and a teacher are data source, the data shows in this study as the competence of the teacher to make plan, do the action and the students activities in the learning teaching process. The data collecting is observation sheet and interview and teacher performance evaluation in which the seven components of CTL

The result of the study shows that the applaying of CTL approach through Task and Model Strategy as the sustainable Academic Supervision on guru Bahasa Indonesia of SMP Negeri 4 Sungai Ambawang Kabupaten Kubu Raya Academic Year 2010-2011 improve the teachers competence in planning action and action and the students result in learning effectively.

Keyword: CTL,approach, task and model, academic supervision

\section{PENDAHULUAN}

\footnotetext{
${ }^{1}$ Abdulah adalah Pengawas SMP Kabupaten Kubu Raya
} 
Pembelajaran dengan pendekatan contextual teaching and learning adalah pendekatan yang dapat menyenangkan siswa dan membantu guru dalam proses pembelajaran. Menyenangkan siswa karena proses pembelajaran yang menggunakan pendekatan ini berpusat pada siswa. Aktivitas siswa lebih banyak karena harus melakukan tujuh komponen CTL, yaitu contructivism, questioning, inquiry, learning community, modeling, authentic assessement and reflection. Menyenangkan guru karena dengan pendekatan CTL ini guru dalam melaksanakan kegiatan belajar mengajar hanya bertindak sebagai fasilitator.

Kepres Nomor 1 Tahun 2010 tentang Penguatan Pengawas Sekolah seIndonesia menitikberatkan pada tiga materi pokok dalam kegiatan pembinaan akademik. Materi pokok pada kegiatan penguatan tersebut ada tiga, yaitu Evaluasi Diri Sekolah (EDS), Penelitian Tindakan Kelas (PTK), dan Pembelajaran Aktif Inovatif Kreatif Efektif dan Menyenangkan (PAIKEM). Khusus untuk pembinaan tenaga pendidik materi pokoknya adalah PAIKEM yang di dalamnya menekankan pada pendekatan $C T L$ yang merupakan sasaran utamanya. Ketiga materi tersebut merupakan amanah dalam Kepres tersebut untuk dikembangkan secara berjenjang dan menyeluruh serta berkesinambungan.

Output yang diharapkan dari hasil penguatan pengawas sekolah tersebut adalah terwujudnya pengawas sekolah yang terampil membimbing guru dalam menerapkan tiga materi pokok tersebut khususnya CTL dalam proses pembelajaran. Untuk itu penulis merasa berkewajiban mengembangkan materi penguatan tersebut khususnya $C T L$ dalam rangka meningkatkan kualitas proses pembelajaran bahasa Indonesia di SMP Negeri 4 Sungai Ambawang yang merupakan satu di antara sekolah binaan penulis sebagai Pengawas Sekolah Kabupaten Kubu Raya Tahun Pelajaran 2010/ 2011.

Ada beberapa alasan penulis mengambil lokasi penelitian pada guru Bahasa Indonesia di SMP Negeri 4 Sungai Ambawang, di antaranya adalah:

1. SMP Negeri 4 adalah termasuk sekolah binaan penulis, sehingga penulis mempunyai kewajiban meningkatkan kompetensi seluruh stakeholdernya khususnya guru Bahasa Indonesia yang ada di sekolah tersebut.

2. Menurut Kepala SMP Negeri 4 Sungai Ambawang belum ada guru Bahasa Indonesia di SMP Negeri 4 Sungai Ambawang mendapatkan pelatihan secara khusus tentang pendekatan CTL (Surat Pernyataan Kepala Sekolah terlampir).

3. Literatur dan pedoman tentang $C T L$ di sekolah tersebut sangat terbatas.

4. Guru Bahasa Indonesia hanya satu orang sehingga sulit melakukan tukarmenukar pendapat tentang hal-hal yang baru dan prinsip khususnya $C T L$. 
5. RPP yang dibuat oleh guru Bahasa Indonesia di sekolah tersebut belum memperlihatkan penyesuaian dengan lingkungan dunia nyata siswa di SMP Negeri 4 khususnya pada materi ajar yang masih mengutip cerita dari daerah lain, yaitu Birma.

Candlin (2001:7) dalam Kasiani dan Suyanto menjelaskan bahwa hampir semua prinsip CTL cocok untuk proses pembelajaran bahasa. Berdasarkan pendapat tersebut dapat penulis simpulkan bahwa setiap perubahan kurikulum ada kekhasannya dengan menitikberatkan pada pendekatan tertentu. Misalnya Kurikulum 1984 penekanan pendekatan yang harus dilaksanakan guru adalah CBSA. Kurikulum 1994 pendekatan yang menjadi penekanannya khusus pada pengajaran bahasa Indonesia adalah pembelajaran Komunikatif. Dan KTSP menekankan pendekatan pembelajaran pada CTL. Hal itu juga sejalan dengan Panduan KTSP (2008:6) dalam pengembangan model pembelajaran tatap muka, penugasan terstruktur, dan tugas mandiri tidak terstruktur dipandang sebagai salah satu strategi yang memenuhi prinsip pembelajaran kontekstual.

Selanjutnya dijelaskan pula bahwa ada tujuh pilar yang harus dilakukan guru dalam pembelajaran kontekstual, yaitu: contructivisme, inquiry, quetioning, learning komunity, modeling, reflection, authentic assessment.

Komponen-komponen dalam tujuh pilar CTL tersebut menurut penulis adalah merupakan konsep pembelajaran yang dapat membantu guru dalam hal:1.Mengaitkan antara materi pembelajaran dengan situasi dunia nyata siswa. 2.Membuat hubungan antara pengetahuan yang dimlikinya dengan penerapannya dalam konteks kehidupan sehari-hari. 3.Menempatkan siswa di dalam konteks yang bermakna yang berhubungan dengan pengetahuan awal siswa dengan materi yang sedang dipelajarinya. 4.Materi dimulai dari hal-hal yang konkrit ke konsep/ abstrak. 5.Pembelajaran menyenangkan dan aktif. 5.Siswa praktik bukan menghafal. 6.Pembelajaran berpusat pada siswa. 7.Mengutamakan pengalaman nyata. 8.Siswa aktif, kreatif, kritis, inisiatif, menantang, dan menyenangkan (sesuai PP 19 Tahun 2005). 9.Learning bukan teaching. 10.Pendidikan (education) bukan pengajaran (instruction). 11.Hasil belajar diukur dengan berbagai cara, bukan hanya dengan tes.

Kedua belas komponen tersebut apabila guru dapat menerapkannya dengan baik akan sejalan dengan upaya pemerintah dalam mengembalikan karakter bangsa khususnya para pelajar yang sudah memudar akhir-akhir ini.

Dengan menggunakan pendekatan $C T L$ dapat mengubah kondisi pembelajaran dari konvensional yang berpusat pada guru sehingga disenyalir dapat menurunkan karakter para pelajar khususnya dan pendidikan Indonesia pada umumnya karena dengan model pembelajaran konvensional dapat memciptakan para pelajar hanya dapat menerima ilmu pengetahuan dari guru 
mereka saja tanpa mau berusaha sendiri dengan giat, ke pembelajaran yang berpusat pada siswa. Dengan demikian maka siswa tidak hanya asal menerima dari guru saja yang pada akhirnya akan menciptakan siswa tidak aktif, pemalas, lamban berpikir karena tidak pernah dilatih, mudah lupa karena hanya mendengar dan tidak pernah berbuat. Ini sejalan dengan pendapat Khan (2010:7-9) yang menjelaskan ada tujuh komponen karakter bangsa khususnya para pelajar saat ini yang perlu diberantas oleh guru. Ketujuh karakter tersebut adalah: 1. Konsentrasi yang terpisah, 2. Etos kerja rendah, 3. Lamban, 4. Pelupa, 5. Potensi terpendam, 6. Emosional smart rendah, 7. Intrapersonal smart rendah.

Strategi pemodelan menurut penulis adalah sebuah strategi yang dapat mempermudah dalam memahami konsep ilmu pengetahuan tertentu. Hal itu karena kemampuan memahami suatu konsep sangat berbeda untuk setiap orang. Ada orang yang langsung paham dengan membaca sumbernya saja. Ada pula yang perlu penjelasan orang lain. Tetapi ada yang baru paham setelah melihat model atau contoh dari nara sumber. Berdasarkan pengalaman, untuk dapat mempermudah orang memahami konsep diperlukan contoh atau model. Model dapat mempermudah dan memperkuat pemahaman orang tentang konsep yang disampaikan.

Strategi pemodelan dan pemberian tugas ini menurut penulis belum pernah dilakukan para peneliti khususnya di SMP Negeri 4 Sungai Ambawang Kabupaten Kubu Raya. Dan kedua trategi ini menurut penulis sangat efektif dalam melakukan tindak lanjut hasil supervisi akademik. Agar kekurangan yang dialami guru yang disupervisi dapat ditingkatkan. Untuk itu penulis merasa tertarik menggunakan kedua strategi ini dalam penelitian ini.

Pembelajaran dengan pendekatan Contextual Teaching and Learning merupakan konsep belajar dalam rangka membantu guru mengaitkan materi yang diajarkan dengan situasi dunia nyata siswa dan mendorong siswa membuat hubungan antara pengetahuan yang dimilikinya dengan penerapannya dalam kehidupan mereka sebagai anggota keluarga dan masyarakat, Depdiknas (2002: 1).

Johnson (2006: 65) menjelaskan bahwa CTL adalah sebuah sistem pembelajaran yang menyeluruh, yang terdiri dari bagian-bagian yang saling berhubungan agar dapat memberikan pengaruh yang melebihi daripada terbagi-bagi. Selanjutnya Johnson (2006: 88) menjelaskan bahwa CTL membantu siswa menemukan makna dalam pelajaran mereka dengan cara menghubungkan materi akademik dengan konteks kehidupan mereka. Mereka membuat hubungan-hubungan penting yang menghasilkan makna dengan melaksanakan pembelajaran yang diatur sendiri, bekerja sama, berpikir kritis, mencapai standar tinggi, dan berperan serta dalam tugas-tugas penilaian 
autentik. Muchith (2007: 2) menjelaskan bahwa pembelajaran kontektual lebih menekankan pada idealisme pendidikan sehingga benar-benar akan menghasilkan kualitas pembelajaran yang efektif dan efisien.

Muhammad (2008: 3) menjelaskan bahwa pembelajaran kontektual merupakan konsep pembelajaran yang membantu guru dalam mengaitkan materi pembelajaran dengan kehidupan nyata.Trianto (2009: 104) menjelaskan bahwa pengajaran dan pembelajaran kontekstual atau contextual teaching and learning (CTL) merupakan suatu konsepsi yang membantu guru me:ngaitkan konten mata pelajaran dengan situasi dunia nyata dan memotivasi siswa membuat hubungan antara pengetahuan dan penerapannya dalam kehidupan mereka.

Selanjutnya Komalasari (2010: 6) mengutip pendapat Blachd (2001: 2) mengemukakan bahwa "contextual teaching and learning is is a conception of teaching and learning that helps teacher relate subject matter content to real world situations, and motivates student to make connections between knowledge and is applications to their lives as family members, citizens, and workers and engage in the hard work that learning requirs."

\section{B. Tujuan Pendekatan $C T L$ dalam Proses Belajar Mengajar}

Pembelajaran kontektual bertujuan membekali siswa dengan pengetahuan yang lebih bermakna secara fleksibel dapat diterapkan (ditransfer) dari satu permasalahan ke permasalahan lain dan dari satu konteks ke konteks yang lainnya, Muhammad (2008: 4). Menurut Johnson (2006: 182) menjelaskan bahwa pembelajaran dengan pendekatan $C T L$ bertujuan untuk membantu siswa dalam rangka mengembangkan potensi intelektual mereka, karena CTL mengajarkan langkah-langkah yang dapat digunakan dalam berpikir kritis dan kreatif serta memberikan kesempatan untuk menggunakan keahlian berpikir dalam tingkatan yang lebih tinggi dalam duania nyata, yaitu dunia yang dialami oleh mereka.

Berpijak dari tujuan di atas, maka pembelajaran dengan pendekatan $C T L$ ini diharapkan hasilnya dapat lebih bermakna bagi siswa untuk memecahkan persoalannya dengan pengalamannya dan terlatih berpikir kritis yang diperolehnya di bangku pendidikan. Pengalaman ini diharapkan menjadi modal dalam menjalani kehidupannya di masyarakat.

\section{Komponen dalam Pembelajaran Kontektual}

Pada proses pembelajaran terdapat tujuh (7) komponen CTL yang harus yang harus dikuasai oleh guru, ketujuh komponen yang dimaksud adalah: 


\section{Kontruktivisme ( Contructivism)}

Ramly (2010: 12) menandaskan bahwa manusia mengkontruksi (membangun) makna dari struktur pengetahuan aktual yang dimiliki. Kontruktivisme menekankan kegiatan belajar yang berkembang melalui dukungan fasilitator atau guru. Komponen kontruktivisme adalah: a.Melibatkan siswa aktif dalam merancang, melaksanakan, dan meevaluasi pembelajaran. b.Membangun pemahaman mereka sendiri dari pengalaman baru berdasar pada pengetahuan awal. c.Pembelajaran harus dikemas menjadi proses "mengkonstruksi" bukan menerima pengetahuan. d.Merasakan langsung manfaat pembelajaran/mempunyai pengalaman. e.Bekerja sama dengan tim. f. Pembelajaran dikaitkan dengan dunia nyata. g. Membangun pengetahuan awal dengan materi yang dipelajari. h. Siswa diberi peluang dan dihargai dalam PBM. i.Guru hanya sebagai fasilitator dalam PBM. j. Guru menggunakan berbagai teknik dalam PBM. k. Lingkungan belajar bersifat dinamis. i.Guru dan siswa terdorong untuk lebih kreatif melakukan percobaandan teknik untuk pembelajaran baru.

\section{Bertanya (Questioning)}

Komponen ini menuntun guru dalam kegiatan pembelajaran agar guru mampu merancang pertanyaan-pertanyaan sehingga kelas menjadi lebih hidup. Pertanyaan juga dapat meransang siswa untuk berpikir. Berikut adalah komponen pertanyaan yang harus diperhatikan dan dilaksanakan guru di kelas. a. Pertanyaan yang dibangun guru adalah untuk menggali informasi tentang pengetahuan awal akademis siswa. b. Pertanyaan yang dilakukan oleh guru adalah untuk mengecek pemahaman siswa. c.Kegiatan tanya jawab lebih banyak dibandingkan dengan mendengar. d.Terjadi tanya jawab antara guru dengan murid, antara murid dengan murid pada PMB. e. Pertanyaan yang dilakukan menggiring dalam pencapaian tujuan pembelajaran. f.Pertanyaan guru untuk membangkitkan respon siswa. g.Pertanyaan yang dilakukan oleh guru untuk mengetahui sejauh mana keinginan siswa dalam mengikuti pembelajaran. h.Pertanyaan yang dilakukan guru adalah untuk memfokuskan perhatian siswa. i. Pertanyaan yang dilakukan guru untuk menyegarkan kembali pengetahuan siswa. j. Pertanyaan yang dilakukan guru untuk meningkatkan lebih banyak lagi pertanyaan siswa. k.Pertanyaan yang dilakukan oleh guru bersifat menyebar atau terbuka. 1.Kalimat tanya yang dibuat guru singkat dan jelas sesuai sesuai dengan permasalahan yang sedang dibahas.

\section{Inkuiri (Inquiri)}

a. Guru menyempaikan materi dalam bentuk rumusan masalah. 
b. Guru menugaskan siswa untuk menemukan jawaban atau penyelesaian permasalahan dalam sajian mater

c. Guru menyuruh siswa menyampaikan hasil pekerjaannya secara bergantian.

d. Guru menyuruh siswa melengkapi pekerjaan temannya yang belum lengkap.

e. Guru menyuruh siswa lain menilai pekerjaan siswa yang tampil guru menyuruh siswa menyimpulkan jawaban yang benar.

Inti dari komponen ini adalah pertama pembelajaran harus dimulai dengan masalah untuk diselesaikan bersama-sama. Kedua yang aktif menyelesaikan masalah adalah siswa, guru hanya sebagai fasilitator.

\section{Masyarakat Belajar (Learning Community)}

Sagala (2010: 61) menjelaskan bahwa strategi cooperative learning dengan pendekatan $C T L$ dilakukan dengan cara membentuk kelompok dengan tujuan mempermudah peserta didik untuk berinteraksi dan bertukarpikiran. Berikut ini adalah komponen yang harus dibangun oleh guru dalam proses pembelajaran pada pilar yang keempat ini. a. Semua peserta didik aktif dan mendapatkan kesempatan yang sama. b. Waktu yang diberikan untuk suatu kegiatan peserta didik cukup. c.Peserta didik tampak disiplin dalam melaksanakan tugas. d. Adanya instruksi tugas yang jelas dan mudah dipahami oleh peserta didik. e. Jumlah peserta didik berkelompok tidak melebihi 6 orang. f. Adanya target waktu penyelesaian suatu tugas dari guru. g.Tersedianya alat dan bahan yang cukup dalam melaksanakan kegiatan pembelajaran. h.Tampak kegiatan eksplorasi jika dituntut kompetensi yang sedang dikembangkan yang difasilitasi guru. i.Adanya umpan balik antrapeserta didik dalam kelompok, antarkelompok, dan antar guru-kelompok/ seluruh kelas. j. Guru memfasilitasi pembentukan kelompok.. k.Guru menempatkan siswa berdasarkan pemerataan kemampuannya. 1. Guru mengontrol jalannya kegiatan pada semua kelompok. m. Guru mengatur dalam pembagian tugas kerja dalam kelompok. n.Guru mendatangkan ahli dalam kelompok belajar

\section{Pemodelan (Modeling)}

Kegiatan yang dilakukan oleh guru pada komponen ini adalah sebagai berikut:

a. Guru menjelaskan kegiaatan pembelajaran dengan peragaan, contoh, atau pemodelan.

b. Guru mengutamakan siswa lebih banyak sebagai model dalam pembelajaran. 
c. Guru memotivasi siswa agar bersemangat daalam menampilkan pekerjaannya.

d. Guru menghargai tampilan siswa.

e. Guru mendatangkan ahli dalam memberikan pemodelan.

\section{Refleksi (Reflektion)}

Kegiatan yang dilakukan guru pada komponen ini adalah sebagai berikut:

a. Menanyakan kembali tentang apa-apa yang diperoleh siswa dari hasil pembelajaran.

b. Mencatat hal-hal penting / rangkuman secuai dengan tujuan pembelajaran yang telah disepakati bersama dalam proses pembelajaran.

c. Memberikan penekanan pada konsep yang harus dikuasai siswa.

d. Memberi atau mempersilahkan siswa untuk mencatan rangkuman yang telah ditulis.

e. Meminta siswa untuk menyampaikan kesan dan pesan dari proses pembelajaran yang telah berlangsung.

\section{Penilaian Autentik ( Utentic Assessement )}

a. Penilaian yang dilakukan dalam proses pembelajaran.

b. Penilaian yang dilakukan setelah proses pembelajaran.

c. Penilaian yang dilakukan adalah keterampilan performansi, bukan hanya mengingat fakta.

d. Penilaian dijadikan feed back

Penilaian berbentuk: (a) Laporan kegiatan/ proyek, (b) PR, (c) Kuis, (d) Presentasi/ penampilan siswa, (e) Karya siswa,(f) Demontrasi, (g) Jurnal, (h) Tes. Penekanan penilaian autentik adalah pada proses dan hasil. Jadi, agar penilaian itu dapat dikatakan penilaian autentik tentulah penilaian yang dilakukan oleh banyak orang (siswa dan guru). Jika penilaian itu hanya dilakukan oleh guru kemungkinan masih ada unsur subjektifnya.

\section{Pembelajaran Bahasa Indonesia dengan Pendekatan $C T L$}

Jika dipahami dan dicermati dengan baik, maka dalam pembelajaran bahasa khususnya Bahasa Indonesia sangat memungkinkan menggunakan pendekatan CTL. Candlin( 2001: 7) dalam makalah Kasiani K.E.Suyanto, menjelaskan bahwa hampir semua prinsip CTL cocok untuk PBM bahasa. Selanjutnya dijelaskannya bahwa guru tidak mampu memberi semua pengetahuannya semua kepada muridnya. Oleh karena itu di dalam proses pembelajaran dengan pendekatan $C T L$, guru melatih siswa untuk membangun 
sendiri pengetahuan mereka. Misalnya dalam mengajarkan empat (4) aspek keterampilan berbahasa bermula dari hal yang sederhana sampai pada yang lebih kompleks. Dari hanya mengenal huruf membaca dan menulisnya, sampai pada membaca dan menulis karya yang sangat kompeleks. Penggabungan pengetahuan yang disampaikan guru dengan usaha mandiri siswa merupakan aplikasi konstruktivime. Perkembangan pengetahuan bahasa yang semakin dalam dan luas dapat diperoleh dari orang lain atau teman di kelas, ini sudah masuk ke dalam Learning Community. Belajar menyelesaikan sendiri permasalahan bahasa, misalnya mencari makna kata sendiri dalam kamus sudah termasuk inkuiri(inquiry). Keterampilan dan pengetahuan bahasa yang dimiliki seseorang yang paling mudah adalah melalui bertanya, dan seterusnya.

\section{E. Strategi Pemodelan}

\section{Strategi}

Guru sebagai komponen penting dari tenaga pendidik, memiliki tugas untuk melaksanakan proses pembelajaran. Dalam pelaksanaan pembelajaran, guru diharapkan paham tentang pengertian strategi pembelajaran. Wena (2009 : 2) menjelaskan bahwa strategi berarti cara dan seni dalam menggunakan sumber daya untuk mencapai tujuan tertentu. Berikut ini adalah contoh yang berkaitan dengan strategi, yaitu:

a. Dalam peperangan digunakan strategi peperangan dengan menggunakan sumber daya tentara dan peralatan perang untuk memenagi peperangan.

b. Dalam bisnis digunakan strategi bisnis dengan mengerahkan sumber daya yang ada sehingga tujuan perusahaan untuk mencapai keuntungan tercapai.

c. Dalam pembelajaran digunakan strategi pembelajaran dengan menggunakan sumber daya (guru dan media) untuk mencapai tujuan pembelajaran.

Etimologi, strategi adalah rencana yang cermat mengenai kegiatan untuk mencapai tujuan, (Depdikbud1991: 964). Berdasarkan pendapat tersebut dapat penulis jelaskan bahwa strategi adalah suatu cara yang telah ditetapkan untuk mempermudah dalam melaksanakan suatu kegiatan. Tanpa strategi, sudah pasti pelaksanaan suatu pekerjaan yang akan kita laksankan akan mengalami kesulitan dalam pencapaian tujuannya. Dalam proses belajar mengajar, guru diharapkan mampu membuat strategi kegiatan pembelajarannya dengan tepat agar tujuan yang diinginkan dapat mudah terwujud. Pemilihan pendekatan, model, dan metode pembelajaran adalah merupakan sebuah strategi pembelajaran. Dengan demikian, dapat disimpulakan bahwa strategi pembelajaran merupakan serangkaian seni dan cara untuk melaksanakan suatu kegiatan dalam menetapkan pendekatan, model, dan metode pembelajaran. 


\section{Pemodelan}

\section{a. Pengertian Pemodelan}

Pemodelan atau modeling adalah upaya memberikan penjelasan secara konkrit melalui contoh-contoh. Dikatakan konkrit karena melalui pemodelan seseorang dapat langsung menyaksikan atau melihat proses dalam suatu kegiatan. Pemodelan dapat juga diartikan melakukan peragaan, memberi contoh dan mendemontrasikan suatu kegiatan.

\section{b. Tujuan Pemodelan}

Tujuan melakukan pemodelan adalah agar seseorang dapat mengetahui, melihat secara langsung tanpa melalui perantaraan redaksi, ungkapan tertulis, atau pernyataan yang berbentuk uraian tertulis. Hal itu penting, karena kemampuan dan cara orang menerima ilmu sangat bervariasi. Ada yang cukup dengan penjelasan lisan, ada yang tertulis, ada juga yang membutuhkan banyak contoh atau peragaan atau modeling. Dari sekian banyak cara, bentuk memberi contoh atau pemodelan inilah yang sangat efektif dalam menanamkan pemahaman pada seseorang terhadap konsep sesuatu karena ia langsung mengamati prosesnya. Contoh umum: Seseorang akan menjelaskan proses membuat panganan tertentu, biasanya ia mendemontrasikan proses pembuatannya, sehingga peserta yang menyaksikannya dapat melihat langsung prosesnya. Dengan harapan dapat pula melakukannya sendiri setelah memperhatikan peragaan tersebut. Berdasarkan uraian di atas, lalu siapa yang berhak melakukan melakukan pemodelan atau mendemontrasikan sesuatu? Tentu saja jawabannya adalah siapa saja boleh, yang penting telah menguasai konsep atau materi yang akan diperagakan atau dimodelkan. Selian menguasai konsepnya, ia juga sudah pernah mencoba melakukannya dengan baik.

Tujuan pemodelan dalam proses pembelajaran adalah agar prosesnya menjadi lebih menarik. Karena di dalam memodelkan sesuatu sangat dipengaruhi oleh karaktristik si pemodel. Ada pemodel yang punya karaktristik pemalu, ada yang pemarah, ada yang bersuara kecil atau rendah ada yang bersuara keras. Dengan keunikan masing-masingini, maka pembelajaran menjadi sebuah tontonan yang menarik. Jika pembelajaran menarik, pastilah waktu 2 sampai 3 jam menjadi tidak terasa. Pembelajaran yang menyenangkan akan membekas lebih lama pada peserta didik. Namun sebaliknya, jika pembelajaran disajikan monoton dan tidak menarik, maka waktu 2 sampai 3 jam terasa cukup lama dan membosankan peserta didik. Hasilnya tidak akan membekas lama karena siswa merasa terbebani.

c. Persyaratan Pemodel

Menjadi pemodel tentu harus memenuhi persyaratan. Persyaratan yang umum di antaranya adalah: 1.Memahami konsep tentang materi yang akan 
disampaikan. 2.Termasuk pimpinan, pembina dari dari suatu group. 3.Pendidikan minimal sama pemodel dengan yang dimodel. 4. Bersertifikat sebagai pelatih atau nara sumber.

\section{G. Strategi Pemberian Tugas}

Dalam kegiatan pembelajaran baik kepada siswa maupun guru dalam suatu pelatihan misalnya, pemberian tugas ini sangat penting dilakukan. Pemberian tugas pasca pelatihan atau yang dikenal dengan istilah $O n$ the Job Learning dimaksudkan adalah suatu upaya yang dilakukan narasumber agar peserta pelatihan itu dapat mendalami dan mengembangkan materi pelatihan atau pembelajaran yang telah diterimanya. Dalam hal pemberian tugas ini Joyce, Weil, Calhoun (2009 : 421 ) menjelaskan bahwa kontribusi utamanya dalam pembelajaran adalah penjabaran tugas dan analisis tugas. Prinsip-prinsip rancangan instruksional yang biasanya dilakukan mereka ajukan fokus pada konseptualisasi performa pembelajar ke dalam tujuan dan tugas-tugas, menguraikan tugas-tugas tersebut ke dalam komponen-komponen yang lebih kecil, mengembangkan latihan-latihan yang memastikan adanya penguasaan terhadap masing-masing komponen, dan pada akhirnya dapat menyusun seluruh situasi pembelajaran ke dalam rangkaian-rangkaian yang memastikan adanya transfer antar satu komponen dengan komponen lainya serta terpenuhinya persyaratan pembelajaran sebelum menapak pembelajaran yang lebih tinggi.

Silberman (2011: 134) menjelaskan bahwa pemberian tugas adalah satu cara untuk membantu membangun gambaran tentang materi yang diajarkan dengan cara meminta peserta untuk mempraktikkan atau menerapkan prosedur yang telah dijelaskan oleh nara sumber. Inti dari pendapat di atas adalah yang dimaksud dengan strategi pemberian tugas adalah cara yang dilakukan oleh penyaji dengan memberi sejumlah tugas untuk mempraktikkan konsep yang telah disampaikan oleh penyaji.

Tugas merupakan penilaian hasil kinerja dan tergolong dalam penilaian alternatif yang memerlukan standar kriteria tertentu. Munthe (2009: 130) menjelaskan ada tiga ciri standar tugas yang dimaksud, yaitu: 1.Menunjukkan taksiran angka atau kuantitas tertentu. 2. Dapat dibuktikan secara logis. 3.Bersifat kontektual.

Selanjutnya Beliau mengemukakan bahwa ada 10 macam Standar dan Kriteria tugas, yaitu: 1. Standar dan kriteria penilaian tugas makalah. 2.Standar dan kriteria penilaian presentasi tugas makalah. 3.Standar dan kriteria penilaian tugas proposal (skripsi, tesis, disertasi. 4.Standar dan kriteria penilaian tugas skripsi, tesis, disertasi. 5.Standar dan kriteria penilaian ujian presentasi skripsi, tesis, disertasi. 6.Standar dan kriteria penilaian proposal 
proyek (mini research. 7.Standar dan kriteria penilaian presentasi (lisan) hasil proyek (mini research). 8.Standar dan kriteria penilaian laporan laporan hasil proyek (mini research). 9.Standar dan kriteria penilaian partisipasi, kontribusi, dan keaktifan kelas. 10.Standar dan kriteria penilaian praktik.

\section{H . Supervisi Akademik}

\section{Pengertian Supervisi Akademik}

Supervisi berasal dari kata "super" dan "vision" super artinya tinggi, atas dan vision artinya melihat, memandang. Supervision artinya melihat dari atas. Pengertian tersebut mengandung makna, bahwa supervisi adalah suatu proses kegiatan dalam rangka memantau atau mengobservasi yang dilakukan atasan terhadap bawahannya dalam suatu tugas tertentu sesuai dengan kewenangan yang diberikan padanya. Artinya kalau bukan kewenangannya tentu saja dia tidak berhak melakukan pemantauan dalam rangka melakukan penilaian karena bukan kewenangannya dan bukan tugas pokoknya untuk melakukan itu. Hasilnya pun tidak dapat digunakan untuk memberikan pertimbangan. Misalnya guru mensupervisi kepala sekolah atau guru CPN mensupervisi guru PN, hasil supervisinya tidak dapat digunakan untuk memberikan pertimbangan. Yang berhak mensupervisi kepala sekolah adalah pengawas, pejabat dinas pendidikan, atau kepala sekolah yang dianggap senior. Sudjana (2008:3)

\section{Tujuan Supervisi Akademik}

Tujuan supervisi pada umumnya adalah: pertama memperbaiki sesuatu yang disepakati bersama memang belum baik. Artinya kekeliruan yang dilakukan memang fakta dan disadari oleh pelakunya sehingga sangat diperlukan perbaikan agar tujuan

bersama dapat tercapai sesuai dengan ketentuan yang berlaku. Kedua adalah upaya membantu dan melakukan pembinaan oleh atasan terhadap bawahan. Contohnya pengawas sekolah melakukan supervisi pada guru atau kepala sekolah, tentu tujuannya bukanlah mencari-cari kesalahan. Namun justru sebaliknya, yaitu mencari solusi perbaikan secara bersama-sama artinya shaaring pendapat atau pengalaman.

\section{MASALAH}

Bagaimanakah peningkatan perencanaan, pelaksanaan dan penilaian dengan Penerapan pendekatan CTL pada Guru Bahasa Indonesia di SMP Negeri 4 Sungai Ambawang Kabupaten Kubu Raya Tahun 2011 melalui Strategi Pemodelan dan Pemberian Tugas sebagai Tindak Lanjut Supervisi Akademik? 


\section{TUJUAN PENELITIAN}

Penelitian Tindakan Sekolah ini mempunyai empat tujuan utama seperti berikut ini:

1. Untuk mengetahui kemampuan Guru Bahasa Indonesia merumuskan Rencana Pembelajaran dengan pendekatan CTL.

2. Untuk membantu Guru Bahasa Indonesia dalam melaksanakan proses pembelajaran dengan pendekatan $C T L$.

3. Meningkatkan kemampuan guru dalam melaksanakan penilaian dengan pendekatan $C T L$.

4. Memotivasi guru dalam mengembangkan pendekatan $C T L$ dalam proses pembelajaran sesuai pendekatan pembelajaran yang dianjurkan dalam KTSP.

\section{MANFAAT PENELITIAN}

Kegiatan penelitian ini mengandung banyak mafaat yang dirasakan oleh penulis dan seluruh personal yang terkait di antaranya adalah sebagai berikut:

a. Manfaat Teorits

Manfaat teoritis dari penelitian ini adalah sebagai sumbangsih untuk dunia pendidikan khususnya guru bahasa Indonesia yang berkeinginan memahmi secara baik pendekatan pembelajaran $C T L$. Selain pendekatan CTL, pada tulisan ini juga mengajak para pakar dan praktisi pendidikan dalam menanamkan konsep sangat diperlukan model atau contoh konkrit dari nara sumber. Selanjutnya agar hasil yang dicapai dari suatu kegiatan pelatihan seperti sosialisasi, IHT, Workshop dan sebagainya, perlu diberi penugasan agar peserta atau yang menerima materi tersebut menjadi berpengalaman sehingga akan terjadi penggabungan antara teori dengan praktiknya. Dengan demikian, maka teori yang masih bersifat verbalime akan menjadi hal yang nyata atau kontektual.

b. Manfaat Praktis

1. Manfaat bagi peneliti

a. Dapat meningkatkan profesionalisme peneliti sebagai pengawas. Hal itu karena kegiatan ini merupakan salah satu dari enam kompetensi yang harus dikuasai oleh seorang pengawas. Kompetensi yang dimaksud adalah penelitian dan pengembangan yang merupakan tambahan dari kompetensi guru dan kepala sekolah.

b. Untuk meningkatkan kemampuan di bidang akademik sesuai dengan bidang tugas yang peneliti ampu.

\section{Manfaat bagi guru}


a. Kegiatan ini juga bermanfaat bagi guru sejalan dengan pelaksanaan tugas rutin pengawas sebagai pembina guru-guru di sekolah binaan dalam rangka menigkatkan mutu pendidikan melalui proses pembelajaran yang bermutu.

b. Menambah pengalaman guru melalui strategi pemodelan dalam prsoses belajar mengajar yang telah dilakukan oleh si pemodel.

c. Menambah pengetahuan dan keterampilan guru dalam proses belajar mengajar melalui pengamatan si pemodel.

\section{Manfaat bagi siswa}

Manfaat yang bagi siswa dari kegiatan penelitian ini adalah sebagai berikut:

a. Dapat membuat siswa belajar lebih bergairah, bersemangat, lebih aktif, kreatif karena kegiatan siswa bervariasi, tidak hanya mendengar dari guru dalam memperoleh informasi.

b. Siswa dapat memahami pengetahuan yang dipelajari lebih lama karena mereka mempunyai pengalaman dari hasil mencari sendiri.

c. Siswa lebih mandiri dalam mencari pengetahuan dan keterampilan yang dikehendakinya.

d. Siswa mendapat penjelasan yang bervariasi melalui sharing siswa dengan guru, siswa dengan siswa, siswa dengan nara sumber.

\section{Manfaat bagi sekolah}

Kegiatan penelitian ini banyak manfaatnya bagi sekolah, diantaranya adalah

a. Dapat membantu pihak sekolah terutama dalam upaya meningkatkan mutu pendidikan di sekolah yang merupakan program utama yang harus dilaksanakan oleh pihak sekolah melalui perbaikan dalam proses pembelajaran yang bervariasi dan bermutu dari si pemodel.

b. Meringankan beban sekolah dalam mendatangkan nara sumber untuk perbaikan mutu pembelajaran.

c. Membantu pihak sekolah dalam menciptakan pemodel di sekolahnya sehingga dapat dikembangkan kepada guru-guru yang lain.

\section{METODE PENELITIAN}

Metode yang peneliti gunakan secara keseluruhan adalah metode kualitatif dengan bentuk deskriptif. Dengan metode ini peneliti berupaya memaparkan data yang terkumpul melalui angket, dokumenter, observasi dan wawancara. Data yang dikumpulkan dipaparkan dalam bentuk kata-kata dan kalimatkalimat. Dan bukan angka angka. Hal itu sesuai dengan metode dan pendekatan yang digunakan oleh peneliti, yaitu metode kualitatif dengan pendekatan deskriptif. Oleh karena itu pengumpulan data yang dilakukan 
adalah dengan cara berulang-ulang sampai pada tingkat kejenuhan data yang diperoleh. Jika sudah sampai pada titik jenuh barulah peneliti berhenti menghimpun data.( Moleong, 1993: 2-6).

Penelitian kualitatif mempunyai dua taraf, yaitu: taraf deskriptif dan taraf inferensial. Taraf deskriptif adalah apabila peneliti hanya semata-mata melukiskan keadaan objek atau peristiwa tanpa bermaksud untuk mengambil kesimpulan yang berlaku secara umum. Sebaliknya dalam taraf inferensial seorang reseach tidak hanya sebatas melukiskan, tetapi dengan keyakinan tertentu mengambil kesimpulan-kesimpulan umum dari bahan-bahan tentang objek yang diteliti. Ariffudin; Saebani (2009: 43)

\section{Teknik Pengumpulan dan Analisis Data \\ a. Teknik pengumpulan data}

Untuk mengumpulkan data dalam suatu penelitin diperlukan teknik tertentu. Nawawi (1985: 242) menjelaskan bahwa ada lima teknik pengumpulan data, yaitu: 1. teknik observasi langsung, 2. teknik observasi tidak langsung, 3. teknik komunikasi langsung, 4. teknik komunikasi tak langsung, 5. teknik studi documenter. Selanjutnya Sugiono (2009: 62) menjelaskan bahwa teknik pengumpulan data dapat dilakukan dengan observasi, interview (wawancara), kuesioner (angket), dokumentasi dan gabungan keempatnya. Berdasarkan kedua pendapat di atas teknik pengumpulan data yang akan penulis gunakan adalah angket, observasi, wawancara dan dokumentasi atau gabungan keempatnya.

\section{b. Teknik analisis data}

Teknik menganalisis data secara kualitatif adalah menetapkan tahap-tahap atau langkah-langkah kegiatan terhadap data yang sedang dan sudah dikumpulkan, dengan tujuan untuk menarik kesimpulan. Hamidi (2008: 97-98) mengemukakan ada empat teknik dalam menganalisis data secara kualitatif, yaitu membuat catatan lapangan, membuat catatan penelitian, mengelompokkan data sejenis, dan melakukan interpretasi dan penguatan. Pada prinsipnya analisis data merupakan sejumlah aktivitas yang dilakukan oleh penulis ketika proses pengumpulan data atau informasi berlangsung, sampai pada penarik kesimpulan berupa konsep atau hubungan antar konsep.

\section{Jenis Penelitian}

Jenis penelitian yang akan penulis gunakan dalam penelitian ini adalah Penelitian Tindakan Sekolah (PTS). Hal itu terkait dengan profesi penulis saat ini yang termasuk tenaga kependidikan (bukan tenaga pendidik), yaitu sebagai Pengawas Sekolah di Kabupaten Kubu Raya. 


\section{Hakikat Penelitian Tindakan Sekolah (PTS)}

Diknas (2009: 36) menjelaskan bahwa apabila penelitian dilakukan oleh guru umumnya disebut dengan Penelitian Tindakan Kelas (PTK). Sedangkan bila penelitian tersebut dilakukan oleh tenaga kependidikan seperti kepala sekolah atau pengawas, maka penelitian tersebut disebut Penelitian Tindakan Sekolah (PTS). Perbedaannya adalah PTK subjek penelitiannya adalah siswa. Sedangka PTS subjeknya adalah tenata pendidik dan tenaga kependidikan. Baedhoi (2009: 10) mempertegas pengertian Penelitian Tindakan Sekolah (PTS). Menurut Beliau Penelitian Tindakan Sekolah (PTS) adalah penelitian tindakan (action research) untuk mengidentifikasi sejumlah permasalahan, merumuskan alternatif pemecahan masalah, menerapkan alternatif yang telah dirumuskan sebagai suatu tindakan, melakukan evaluasi terhadap tindakan dan memberi umpan balik guna menyempurnakan tindakan selanjutnya.

\section{PEMBAHASAN HASIL PENELITIAN}

Hal-hal yang penulis lakukan pada perencanaan tindakan siklus I adalah seperti berikut. Pertama membuat RPP sebagai model atau contoh untuk dicermati dan diikuti guru. Kedua menyampaikan RPP yang telah dibuat oleh penulis pada guru yang diteliti dengan maksud untuk diikuti oleh guru yang bersangkutan. Ketiga adalah memberikan penjelasan-penjelasan yang menyangkut teknis perencanaan, pelaksanaan dan penilaian menggunakan pendekatan CTL. Siklus II merevisi RPP yang telah dibuat oleh guru yang diteliti dan mengidentifikasi permasalahan yang muncul dengan perpedoman pada RPP yang dibuat oleh peneliti, demikian juga pada siklus III sampai guru mampu membuat RPP sesuai dengan contoh yang telah dibuat oleh peneliti.

Siklus I hasil perencanaan pelaksanaan pembelajaran dan penilaian informan pertama baru mencapai $60,71 \%$. Informan kedua baru mencapai $64,3 \%$. Hasil pengamatan perencanaan, pelaksanaan dan penilaian pada siklus II dari tujuh komponen dalam pendekatan $C T L$ semuanya telah tampak dalam pelaksanaan pembelajaran dan penilaian atau mencapai $100 \%$ tercapai. Siklus III perencanaan, pelaksanaan dan penilaian juga mencapai $100 \%$.

\section{SIMPULAN}

Berdasrkan hasil analisis pada bab iv secara umum dapat penulis simpulkan bahwa terdapat peningkatan penerapan Pendekatan Contextual Theaching and Learninga melalui Stratrategi Pemodelan dan Pemberian Tugas sebagai Lindak Lanjut Supervisi Akademik pada guru SMP Negeri 4 Sungai Ambawang Kabupaten Kubu Raya Tahun pelajaran 2010/ 2011.

\section{SARAN}


Berdasarkan kesimpulan di atas penulis menyarankan khusus kepada guru yang penulis teliti agar dalam pelaksanaan tugas akademik khususnya pembelajaran sebaiknya:

1. Perencanaan Pelaksanaan Pembelajaran khususnya yang masih perlu peningkatan seperti tujuan, pendekatan, model, metode, dan teknik pembelajaran memperhatikan secara cermat substasi kurikulum yang berlaku beserta pedoman-pedoman pendukungnya yang telah diterbitkan oleh pemerintah.

2. Dalam penilaan proses, guru sebaiknya mencatat aktivitas semua siswa dalam rangka mengetahui perkembangan peserta didiknya.

3. Dalam rangka implementasi KTSP, sebaiknya guru menerapkan CTL dalam perencanaan, pelaksanaan dan penilaian pembelajaran agar bersifat verbalisme dapat dikurangi.

4. Penulis sadar bahwa tulisan ini tentu masih banyak kekurangannya, untuk itu penulis mohon kritik dan saran para pembaca yang bersifat membangun.

\section{DAFTAR PUSTAKA}

Ariffudin, Saebani, Beni Ahmad 2009. Metodologi Penelitian Kualitatif. Bandung:CV Pustaka Setia.

Baedhoi. 2009. Pedoman Block Grant Penelitian Tindakan Sekolah (PTS) Bagi Pengawas Wilayah Timur dan Daerah Khusus Lainnya. Jakarta: Depdiknas.

Condlin. 2001. CTL Dalam Pengaajaran dan Pembelajaran Bahasa pada Makalah Kasihani K.E Suyanto. Maalang: Tim CTL UM.

Depdikbud. 1991. Kamus Besar Bahasa Indonesia. Jakarta: Balai Pustaka.

Dharma, Surya. 2008. Panduan Pelaksanaan Tugas Pengawas Sekolah/ Madrasah: Jakarta. Depdiknas.

Johnson, Elainne B. 2006. Contextual Teaching \& Learning.Bandung: MLC.

Joyce Bruce, Well Marsha, Calhoun Emily. 2999. Models Of Teaching. Yogyakarta: Pustaka Pelajar.

Khan Yahya. 2010. Pendidikan Karakter Berbasis Potensi Diri. Semarang: Pelangi Publising.

Komalasari, Kokom. 2010. Pembelajaran Kontekstual Konsep dan Aplikasi. Bandung: Aditama.

Moleong, Lexy,J.1993. Metodologi Penelitian Kualitatif. Bandung: PT Remaja Rosdakarya.

Muhammad. 2008. Panduan Pelaksanaan Pembelajaran Kontektual SMP. Jakarta: Depdiknas.

Muchith, M. Saekhan. 2007. Pembelajaran Kontekstual. Kudus: Rasail Media Group. 
Muhajir, As'aril. 2010. Ilmu Pendidikan Perspektif Kontekstual. Jogjakarta: Ar-Ruzz. Media.

Munthe, Bermawi. 2009. Desain Pembelajaran. Yogyakarta: Pustaka Insan Madani.

Nawawi, Hadari. 1985. Metode Penelitian Bidang Sosial. Yogyakarta: Gajahmada University Pers.

Sagala, Syaiful. 2010. Supervisi Pembelajaran. Bandung: Alfabeta.

Silberman, Melvin L. 2011. Actif Learning 101 Cara Belajar Siswa Aktif. Bandung: Nuansa Media.

Sudjana Nana. 2008. Supervisi Akademik. Jakarta: LPP Bima Mitra.

Sugiyono. 2009. Memahami Penelitian Kualitatif. Bandung: Alfabeta.

Trianto. 2009. Mendesain Model Pembelajaran Inovasi Progresif. Surabaya: Kencana Prenada Media Group.

Wena Made. 2009. Strategi Pembelajaran Inovatif Kontenporer. Jakarta: Bumi Aksara 